\title{
Pharmacological studies of the mechanism and function of interleukin-1 $\beta$-induced miRNA-146a expression in primary human airway smooth muscle
}

Hanna M Larner-Svensson ${ }^{1}$, Andrew E Williams' ${ }^{1}$ Eleni Tsitsiou², Mark M Perry ${ }^{1}$, Xiaoying Jiang ${ }^{2}$, Kian F Chung ${ }^{1}$ and Mark A Lindsay*1,2

\begin{abstract}
Background: Despite the widespread induction of miR-146a during the innate immune response little is known regarding its biogenesis, function and mechanism. We have therefore examined the role of miR-146a during the interleukin (IL)-1 $\beta$-stimulated IL-6 and IL-8 release and proliferation in primary human airway smooth muscle (HASM) cells.

Methods: HASM cells were isolated from human lung re-section, cultured to a maximum of 3 - 6 passages and then exposed to IL-1 $\beta$. miR-146a expression were determined by qRT-PCR, IL-6 and IL-8 release by ELISA and proliferation using bromodeoxyuridine incorporation. The role of NF-KB and the MAP kinase pathways was assessed using pharmacological inhibitors of IKK2 (TPCA-1), JNK (SP600125), p38 MAP kinase (SB203580) and MEK-1/2 (PD98059). miR146a function was determined following transfection of HASM with inhibitors and mimics using Amaxa electroporation.

Results: IL-1 $\beta$ induced a time-dependent and prolonged 100-fold induction in miR-146a expression, which correlated with release of IL-6 and IL-8. Exposure to IL-1 $\beta$ had no effect upon HASM proliferation. Pharmacological studies showed that expression of primary miR-146a was regulated at the transcriptional levels by NF-kB whilst post-transcriptional processing to mature miR-146a was regulated by MEK-1/2 and JNK-1/2. Functional studies indicated that IL-1 $\beta$-induced miR-146a expression does not negatively regulate IL-6 and IL-8 release or basal proliferation. However, inhibition of IL$1 \beta$-induced IL-6 and IL-8 release was observed at the super-maximal intracellular miR-146a levels obtained by transfection with miR-146a mimics and indicates that studies using miRNA mimics can produce false positive results. Mechanistic studies showed that in the presence of super-maximal levels, the action of miR-146a mimics was mediated at a step following IL-6 and IL-8 mRNA transcription and not through down-regulation of IL-1 receptor associated kinase 1 (IRAK-1) and TNF receptor-associated factor 6 (TRAF6) protein expression, two predicted miR-146a targets involved in IL-1 $\beta$ signalling.

Conclusions: We have shown that IL-1 $\beta$-induced miR-146a expression in HASM and that this was regulated at the transcriptional level by NF-KB and at the post-transcriptional level by the MEK-1/2 and JNK-1/2. Unlike previous reports, studies using miRNA inhibitors showed that miR-146a expression did not regulate IL- 6 and IL-8 release or proliferation and suggest miR-146a function and mechanism is cell-type dependent.
\end{abstract}

* Correspondence: mark.lindsay@manchester.ac.uk

${ }^{1}$ Airway Disease, National Heart and Lung Institute, Imperial College London SW3 6LY, UK

Full list of author information is available at the end of the article

(c) 2010 Larner-Svensson et al; licensee BioMed Central Ltd. This is an Open Access article distributed under the terms of the Creative :HWed Central Commons Attribution License (http://creativecommons.org/licenses/by/2.0), which permits unrestricted use, distribution, and reproduction in any medium, provided the original work is properly cited. 


\section{Introduction}

Human airway smooth muscle (HASM) cells regulate both the tone and diameter of the respiratory airways. Inappropriate contraction of HASM in response to environmental stimuli is responsible for the reversible airways contraction that is associated with asthma, a chronic disease that affects approximately $10 \%$ of children and $5 \%$ of adults in Western countries [1,2]. In addition to their role in constriction, HASM cells are also thought to contribute towards the chronic inflammation and airway re-modelling that is characteristic of asthma $[3,4]$. Thus, HASM cells have been shown to release a host of inflammatory mediators such as IL-6, IL-8, eotaxin, matrix metalloproteinase- 12 and prostaglandin $E_{2}$ and to undergo proliferation in response to activation via the Toll like receptor (TLR)/interleukin (IL)-1 receptor family [5-13].

Members of the TLR/IL-1 receptor family possess a common intracellular domain and can be subdivided into the TLR family that comprises at least 11 members and the IL-1R family that has 10 members $[14,15]$. The TLRs recognise conserved molecules derived from bacteria, fungi and viruses and contribute towards the innate immune response whilst the IL-1Rs are activated by the pro-inflammatory cytokines, IL- $1 \alpha$, IL- $1 \beta$, IL-18 and IL33 [15]. Agonism of these receptors leads to the activation of a common intracellular signalling pathway. The initial step involves association with the adaptor protein myeloid differentiation primary-response gene 88 (MyD88), which recruits IL-1R associated kinase 1 (IRAK-1) and TNF receptor-associated factor 6 (TRAF6). In HASM cells, these receptors activate a variety of intracellular signalling pathways and pro-inflammatory transcription factors. One of the most important is NF- $k B$, which under basal conditions is localized within the cytoplasm bound to ІкB $\alpha$. Degradation of ІкB $\alpha$ following phosphorylation by I- $\mathrm{kB}$ kinase-2 (IKK-2) results in the nuclear translocation of activated NF- $\mathrm{kB}$, DNA binding and subsequent transcription of multiple inflammatory mediators $[6,16,17]$. Alternative pathways that are known to be activated in HASM cells include the mitogen activated kinase cascades that terminate at ERK-1/2, JNK-1/2 and p38 MAP kinase [6,10,17-21].

miRNA-mediated RNA interference has been identified as a novel mechanism that regulates gene expression at the translational level [22,23]. These short RNA sequences of 20-23 nucleotides are produced by the processing of full length mRNA-like transcripts known as primary miRNAs $[24,25]$. These larger primary miRNA transcripts undergo enzymatic cleavage by the RNAse III enzyme Drosha to produce $\sim 70$ nt precursor miRNAs. These are then transported to the cytoplasm where they are further processed by another RNAse III enzyme, DICER, to produce $\sim 21-23$ double stranded RNA. One strand, the mature miRNA, is then loaded into the RNAinduced silencing complex (RISC) where it is believed to either repress mRNA translation or reduce mRNA stability following imperfect binding between the miRNA and the miRNA-recognition elements (MRE) within the 3 untranslated region (UTR) of target genes. Specificity of the miRNA is thought to be primarily mediated by the 'seed' region that is localised between residues $2-8$ at the 5 ' end [26-28]. Interestingly, recent studies have identified miRNA-mediated RNA interference as a potentially novel mechanism that regulates the immune response [29-31]. In particular, rapid increases in miR-146a and miR-155 expression have been demonstrated in immune cells following activation of members of the TLR/IL-1R family [32-37]. Since these initial observations, miR-155 has been shown to regulate multiple responses associated with the innate and acquired immune response including LPS-induced release of inflammatory mediators from monocytes, T cells and B cells [34,38,39], proliferation and differentiation of myeloid and lymphoid cells [40-44] and B cell antibody switching [45-47]. Significantly, these studies indicate that the function and mechanism of miR155 is dependent upon the cell-type and stage of development/differentiation.

In contrast to miR-155, much less is known regarding the biological role of miRNA-146a. This is despite its widespread induction in both immune and structural cells, such as alveolar and airway epithelial cells, monocytes/macrophages, fibroblasts and chondrocytes following the initiation of the innate immune response [32,4854]. Studies into the mechanisms that regulate miR-146a expression has demonstrated that the initial transcription of primary miR-146a is mediated via activation of NF- $\mathrm{kB}$ $[32,48,49,55,56]$. In contrast, nothing is known regarding the mechanisms that regulate the processing of primary miR-146a to produce the mature miR-146a. Interestingly, recent studies have indicated that TGF $\beta$-induced miR-21 production in human pulmonary artery smooth muscle is primarily regulated at the level of Drosha, which processes primary miR-21 to precursor miR-21, and is driven by activation of the Smad signalling pathway [57]. Evidence of the importance of post-transcriptional regulation has also been provided from studies of the singlestrand RNA-binding protein KH-type splicing regulatory protein (KSRP). This has been shown to serve as a component of both Drosha and Dicer complexes and regulates the biogenesis of a subset of miRNAs through binding with high affinity to the terminal loop of the target miRNA precursors and promoting their maturation [58]. In particular, KSRP has been shown to regulate the maturation miR-155 and the subsequent down-regulation of inflammatory mediators following LPS-stimulation of bone marrow derived macrophages [39]. 
Functional studies indicate that miR-146a negatively regulates the release of inflammatory mediators, although there are differing reports as to the precise mechanism of action [32,48,49]. Taganov et al [32] have suggested that miR-146a targets the down-regulation of IRAK-1 and TRAF6, which are located in the TLR/IL-1R signalling pathway. This hypothesis has been supported by recent studies of miR-146a mediated down-regulation of IFN- $\beta$ release in vesicular stomatitis virus (VSV)infected mouse peritoneal macrophages [49]. In contrast, our previous studies in IL-1 $\beta$-stimulated human alveolar A549 epithelial cells indicated that miR-146a attenuated IL-8 and RANTES release at a step following their transcription and not through the targeting of IRAK1 and TRAF6 [48].

To further characterise the function and mechanism of action of miR-146a, we have examined the IL- $1 \beta$-induced response in primary HASM cells. In contrast to the rapid induction in miR-146a expression previously described $[32,48,49]$, we observed a slow-developing and prolonged induction of miR-146a expression. We have confirmed that NF- $\mathrm{kB}$ regulates miR-146a transcription and demonstrate for the first time, that the post-transcriptional processing of primary miR-146a to mature miR-146a is regulated by MEK-1/2 and JNK-1/2. Significantly, functional studies indicated that IL-1 $\beta$-induced miR-146a expression is not central to the negative regulation of IL-6 and IL-8 release or basal proliferation in HASM cells under physiological conditions. However, we demonstrated that transfection with super-maximal levels of miR-146a could inhibit IL- $1 \beta$-induced IL-6 and IL-8 release and under these conditions, we confirmed our previous observation that the action of miR-146a was mediated at a step following the transcription of IL- 6 and IL-8 and not through down-regulation of IRAK-1 and TRAF6.

\section{Methods}

\section{Ethics Statement}

This study received written approval from the National Heart and Lung Institute and Royal Brompton Hospital NHS Trust Ethics Committee and all subjects gave informed written consent to participate in the study.

Isolation and culture of human airway smooth muscle cells HASM was obtained from lobar or main bronchus of patients undergoing lung resection for carcinoma of the bronchus. The smooth muscle was dissected out under sterile conditions and placed in culture. Cells were maintained in Dulbecco's modified Eagle's medium (DMEM) containing $10 \%$ foetal calf serum (FCS) supplemented with sodium pyruvate $(1 \mathrm{mM})$, L-glutamine $(2 \mathrm{mM})$, penicillin $(100 \mathrm{U} / \mathrm{ml})$ streptomycin $(100 \mu \mathrm{g} / \mathrm{ml})$ and amphotericin $\mathrm{B}(1.5 \mu \mathrm{g} / \mathrm{ml})$ in a humidified atmosphere at $37^{\circ} \mathrm{C}$ in
air/CO2. HASM cells at passages 3-6 from 20 different donors were used in the studies described.

\section{Cell stimulation}

HASM cells were plated onto 6-well plates for assessment of cytokine release and RNA extraction. Prior to experiments, confluent cells were growth-arrested by FCS deprivation for $24 \mathrm{~h}$ in DMEM supplemented with sodium pyruvate $(1 \mathrm{mM})$, L-glutamine $(2 \mathrm{mM})$, nonessential amino acids (1:100), penicillin $(100 \mathrm{U} / \mathrm{ml}) /$ streptomycin $(100 \mu \mathrm{g} / \mathrm{ml})$, amphotericin B $(1.5 \mu \mathrm{g} / \mathrm{ml})$, and bovine serum albumin (0.1\%). Cells were stimulated in triplicate in a fresh FCS-free medium with the indicated IL- $1 \beta$ concentration or with $1 \mathrm{ng} / \mathrm{ml} \mathrm{IL-1} \beta$ for indicated times. To examine the effect of the inhibitors of JNK (SP600125) [54,55], IKK2 (TPCA-1) [56,57], p38 MAP kinase (SB203580) [58,59] and MEK-1/2 (PD98059) [60,61] the indicated concentration (in the range 0.1 to $10 \mu \mathrm{M}$ ) was added $60 \mathrm{~min}$ prior to the addition of IL-1 $\beta(1 \mathrm{ng} / \mathrm{ml})$. At the indicated times, the levels of IL- 6 and IL- 8 were determined by DuoSet ELISA (R\&D Systems) and the remaining cells were extracted for RNA (using a miRVana extraction kit, Ambion).

\section{Measurement of cell number}

After the supernatants were removed from the cells, 200 $\mu \mathrm{l}$ of MTT solution (3-(4,5-dimethylthiazol-2-yl)-2,5diphenyltetrazolium bromide) was added and left to incubate for $30 \mathrm{~min}$ or until sufficient colour developed. Cells were washed and $200 \mu \mathrm{l}$ of DMSO (Sigma-Aldrich) was added to each well. The optical density (OD) was measured at $550 \mathrm{~nm}$ using a spectrophotometer plate reader and expressed as a \% of the control.

\section{Measurement of cell proliferation}

Cell proliferation was quantified using a DNA bromodeoxyuridine (BrdU) incorporation assay (Roche Applied Science, Burgess Hill, UK). The amount of incorporated BrdU is a measure of the rate of DNA synthesis of the cells and thus indirectly of cell proliferation. The cell proliferation kit was used according to the manufacturer's instructions. Briefly, HASM cells were seeded in DMEM containing $10 \%$ FCS in 96-well cell culture plates at a density of 3,500 cells/well. At 30-50\% confluence, the medium was changed to required concentration of FCS and cells were treated with/out IL- $1 \beta(1 \mathrm{ng} / \mathrm{ml})$ for indicated time. At $24 \mathrm{~h}$ prior to the end of the stimulation period, BrdU labelling solution were added to each well at a final concentration of $10 \mu \mathrm{M}$. At the end of the stimulation period, cells were fixed $(60 \mathrm{~min})$ and then incubated for $90 \mathrm{~min}$ at room temperature, with $1 / 100$ dilution of peroxidase labelled anti-BrdU antibody. The wells were then washed three times, incubated for 5 mins at room temperature with substrate solution and the lumines- 
cence was measured using a Fluorostar plate reader (BMG, Offenburg, Germany).

\section{Transfection with miR-146a mimics and inhibitors}

HASM cells were transfected using Basic Nucleofector kit for primary smooth muscle cells according to manufacturer's instructions using Amaxa Nucleofector II device (program P-13) (Amaxa Biosystems, Cologne, Germany). miR-146a mimics and controls were obtained from Ambion/Applied Biosystems Ltd and locked nucleic acid (LNA)-based miR-146a inhibitors and controls were obtained from Exiqon Ltd. Transfected cells were plated into 6-well plates and left to adhere overnight before being serum starved for $6 \mathrm{~h}$ prior to stimulation with 1 $\mathrm{ng} / \mathrm{ml} \mathrm{IL-1 \beta}$. Supernatants were removed at $24 \mathrm{~h}$ and IL6, IL-8 and IFN- levels were determined by DuoSet ELISA (R\&D Systems). The remaining cells were extracted for RNA (using a miRVana extraction kit, Ambion) or tested for viability by MTT assay.

\section{Measurement of miRNAs, primary miR-146a and mRNA expression}

Total RNA was extracted using the mirVana ${ }^{\mathrm{Tm}}$ miRNA isolation kit (Ambion Europe) according to the manufacturer's instructions. RNA was eluted in $50 \mu \mathrm{l}$ RNase-free water (Promega UK, Southampton, UK) and stored at $70^{\circ} \mathrm{C}$. RNA content and purity was measured using a BioTek PowerWave XS (SSi Robotics, Tustin, CA, U.S.A.) spectrophotometer. miRNA expression profiling was carried out on total RNA extracts by two-step TaqMan reverse transcription polymerase chain reaction protocol (RT-PCR) as previously described [36]. mRNA expression levels of IRAK-1, TRAF6, IL-6 and IL-8 was determined using semi-quantitative two-step RT-PCR as previously described [62] using Assay on Demand primer/probe sets obtained from Applied Biosystems, UK. Primary miR-146a expression was determined using RT-PCR and Sybr green detection using the following primers: forward: CAAAGGCTTTGAAGGCCTCTCTA; reverse: ATGGCACCCAGCTGACCAT. All miRNA, primary miRNA and mRNA samples were normalised against $18 \mathrm{~S}$ (Applied Biosystems, Catalogue Number 4310893E). The separate well, 2-( $\Delta \Delta \mathrm{Ct})$ method [63] was used to determine relative-quantitative levels of individual mRNAs, miRNAs and primary miR-146a, and these were expressed as the fold-difference to the relevant controls.

\section{Western Blotting}

Proteins were extracted from HASM cells as previously described [59], separated upon 10\% SDS-PAGE (Invitrogen) and transferred to nitrocellulose (Amersham Ltd). Protein $(20 \mu \mathrm{g})$ were detected by Western blotting using a rabbit anti-TRAF6 antibody (H-274) [60], rabbit anti-
IRAK-1 antibody (H-273)[61] obtained from Santa Cruz Biotechnology. All primary antibodies were used a concentration of 1:200 or 1:400 and were incubated overnight. Labelling of the first antibody was detected using relevant secondary antibodies conjugated to HRP (Dako Ltd) and detected using ECL reagents (Amersham Ltd., UK).

\section{Data and statistical analysis}

The results presented are the mean \pm SEM of at least three independent experiments. Statistical analysis was performed using the Mann-Whitney U-test which assumed non-parametric distribution. P values of $<0.05$ were considered significant and are indicated with asterisks.

\section{Results}

IL-1 $\beta$-induced a time- and concentration-dependent increase in miR-146a expression

As previous investigations have implicated miR-146a and miR-155 in the regulation of TLR/IL-1R-induced response, we measured their expression following exposure to IL-1 $\beta$ ( $1 \mathrm{ng} / \mathrm{ml})$ in HASM cells. Although there was variability between human donors, IL- $1 \beta$ caused a 23 \pm 8 -fold increase in miR-146a expression levels at $6 \mathrm{~h}$, which continued to rise to $81 \pm 29$ and $131 \pm 33$-fold at 24 $h$ and $72 h$, respectively (Figure 1A). In contrast, we observed no significant changes in miR-146a* (reverse strand to the mature miR-146a strand), miR-146b or miR155 levels (Figure 1A). Increasing IL-1 $\beta$ concentration showed that miR-146a expression was maximal at approximately $0.1 \mathrm{ng} / \mathrm{ml}$ (Figure 1B).

In subsequent studies, we measured the levels of the primary miR-146a in response to IL-1 $\beta$. In contrast to mature miR-146a, primary miR-146a expression was increased by only 2-4 fold and maximal release was observed at $6 \mathrm{~h}$, suggesting that the increase in mature miR-146a expression at $24 \mathrm{~h}$ and $72 \mathrm{~h}$ was due to regulation at the post-transcriptional level. Maximal expression of primary miR-146a production was observed at $0.1 \mathrm{ng} /$ ml IL-1 $\beta$ (Figure 2).

\section{IL-1 $\beta$-induced time- and concentration-dependent IL- 6 and IL-8 release}

We subsequently assessed the effect of IL-1 $\beta$ upon the release of the pro-inflammatory mediators, IL- 6 and IL- 8 in HASM cells. IL-1 $\beta$-induced a time- and concentrationdependent release of IL-6 and IL-8 (Figure 3). However, although we observed a significant elevation in both cytokines at $6 \mathrm{~h}$, the IL- 8 response reached a plateau at approximately $24 \mathrm{~h}$, whilst IL-6 continued to increase throughout the $72 \mathrm{~h}$ period (Figure 3A). Examination of the effect of increasing IL- $1 \beta$ upon IL- 6 and IL- 8 release at $24 \mathrm{~h}$ showed similar concentration response curves 

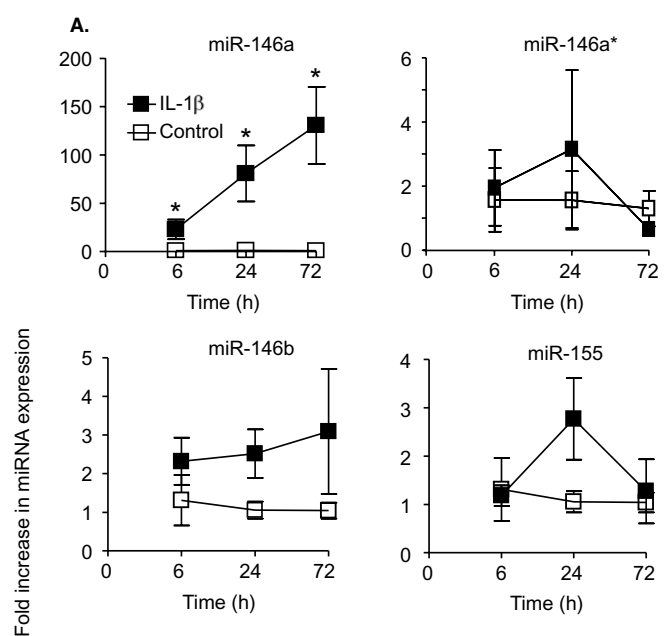

B.

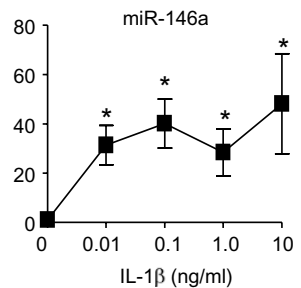

Figure $1 \mathrm{IL}-1 \beta$-induced a time- and concentration-dependent increase in miR-146a expression. HASM cells were exposed to either

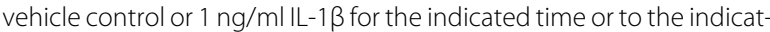
ed IL-1 $\beta$ concentration for $24 \mathrm{~h}$. The time dependent expression of miR-146a, miR-146a*, miR-146b and miR-155 (A) or the concentration dependent miR-146a expression (B) was determined by qRT-PCR. The results are expressed as the mean \pm SEM of four independent experiments where * $p<0.05$ versus time-matched controls.

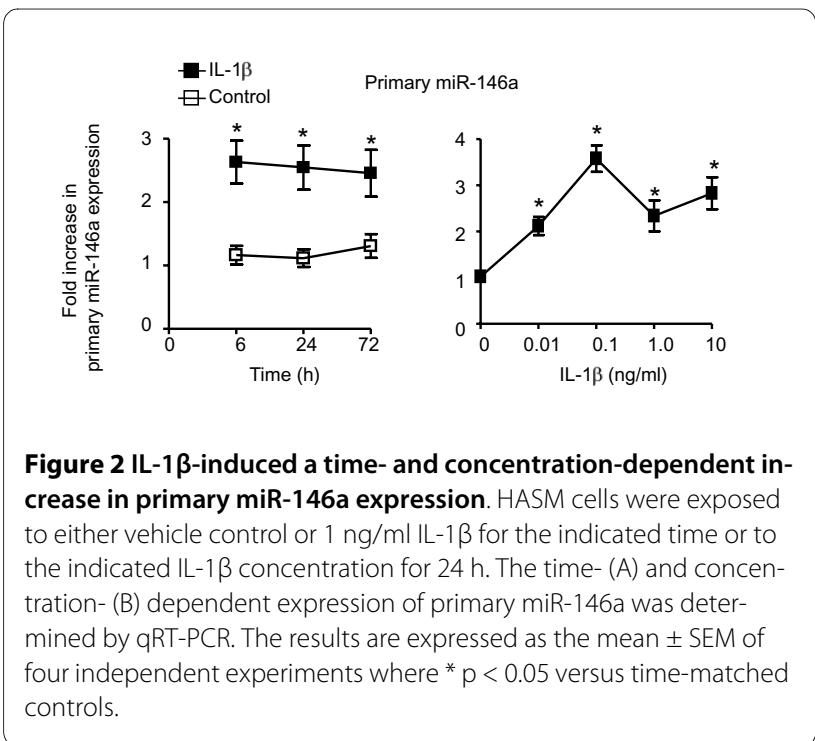

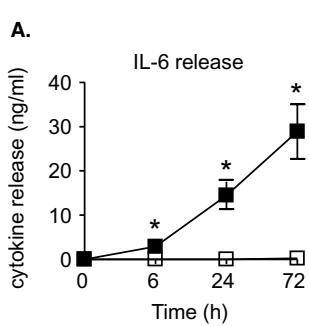
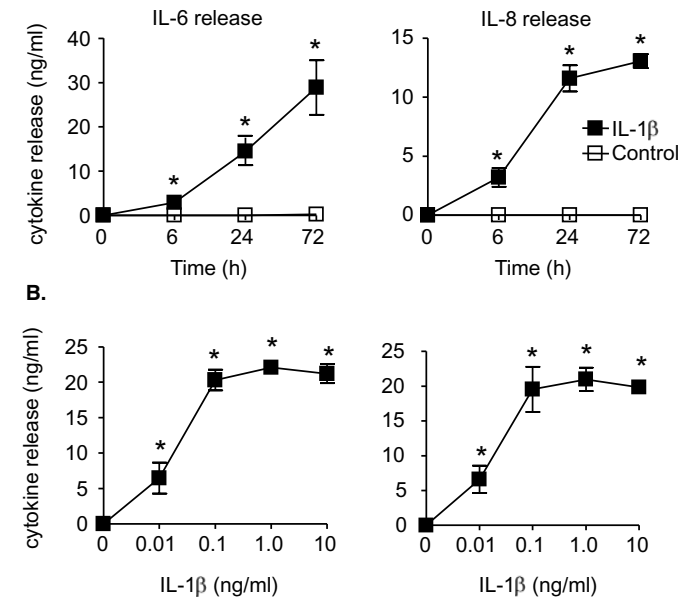

Figure $3 \mathrm{IL}-1 \beta$-induced a time- and concentration-dependent release of IL-6 and IL-8. HASM cells were exposed to either vehicle con-

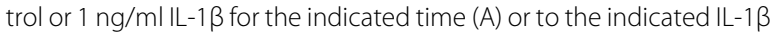
concentration for $24 \mathrm{~h}$ (B) before measurement of IL- 6 and IL-8 release. The results are expressed as the mean \pm SEM of four independent experiments where ${ }^{*} p<0.05$ versus time-matched controls.

with an $\mathrm{EC}_{50}$ value of $\sim 0.03 \mathrm{ng} / \mathrm{ml}$ and maximal release at $1 \mathrm{ng} / \mathrm{ml}$ (Figure 3B). Given that we wanted to examine the role of miR-146a during IL- 6 and IL- 8 release subsequent studies were performed at $1 \mathrm{ng} / \mathrm{ml} \mathrm{IL-1 \beta}$.

\section{IL-1 $\beta$-induced miR-146a expression is regulated at the transcriptional and post-transcriptional level}

In previous studies, we and others have demonstrated that IL- $1 \beta$-induced activation of IKK $2 / \mathrm{NF}-\kappa \mathrm{B}$ and the MAP kinases, ERK-1/2, JNK-1/2 and p38 MAP kinase in HASM cells and that these are inhibited in the presence of the selective pharmacological inhibitors of TPCA-1 (IKK2), PD098059 (MEK-1/2), SP600125 (JNK-1/2) and SB203580 (p38 MAP kinase), respectively [6,10,17-21]. We therefore used the biological active concentrations of these inhibitors to examine the role of the NF- $\mathrm{BB}$ and MAP kinases pathways during miR-146a expression.

Following 60 min pre-treatment with inhibitors, HASM cells were stimulated with IL-1 $\beta$ and the generation of IL6 (Figure 4), IL-8 (Figure 4), miR-146a (Figure 5) and primary miR-146a (Figure 5) were determined at $24 \mathrm{~h}$. Exposure to TPCA-1 completely inhibited production of IL-6, IL-8 and miR-146a expression at $10 \mu \mathrm{M}$. This did not appear to have resulted from cell death since parallel studies showed a small ( $15 \%)$ but non-significant reduction in cell viability (Additional File 1 ). The MEK-1/2 inhibitor $(10 \mu \mathrm{M})$ also attenuated IL-6, IL-8 and miR146a production although this was less pronounced than 

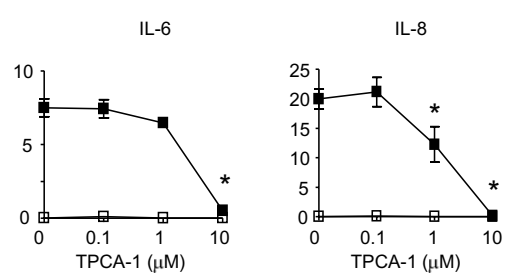

IKK2
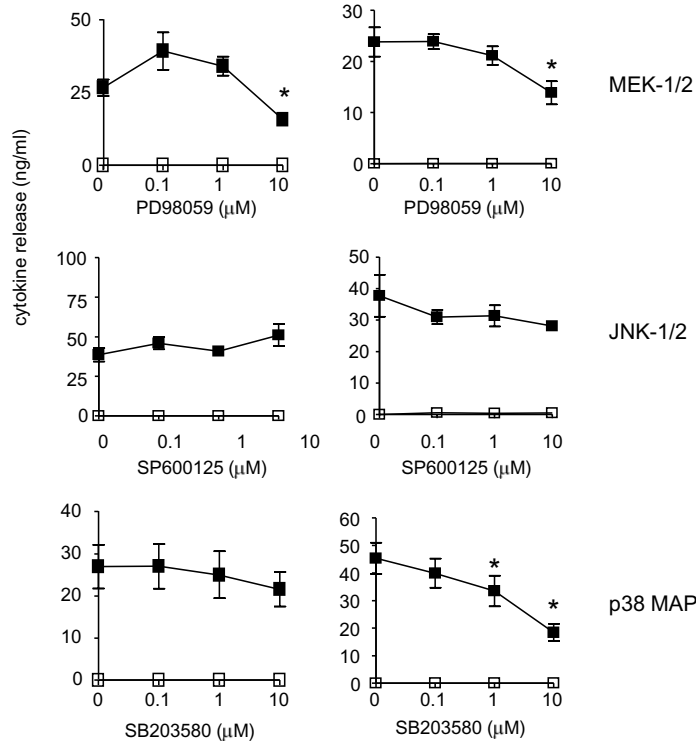

JNK-1/2

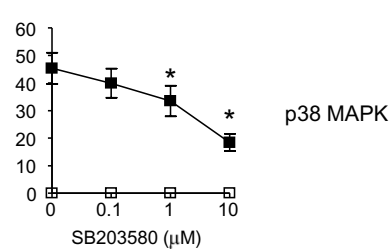

Figure 4 Effect of inhibitors of IKK2 and MAP kinases upon IL-1 $\beta$ induced IL- 6 and IL-8 release. HASM cells were pre-treated for $60 \mathrm{~min}$ with the indicated concentrations of the inhibitors of IKK-2 (TPCA-1), MEK-1/2 (PD098059), JNK-1/2 (SP600125) and p38 MAP kinase (SB203580). Following exposure to vehicle control or IL-1 $\beta(1 \mathrm{ng} / \mathrm{ml})$ for $24 \mathrm{~h}$ the release of IL-6 and IL-8 was determined by ELISA. Results are the mean \pm SEM of 3 independent experiments where ${ }^{*} p<0.05$ versus IL-1 $\beta$-stimulated cells.

TPCA-1 inhibition and resulted in reductions of $\sim 42 \%$, $41 \%$ and $52 \%$, respectively. In contrast, inhibition of the JNK-1/2 (SP600125) and p38 MAP kinase (SB203580) had differential actions upon cytokine and miR-146a production. Thus, JNK-1/2 inhibition had no effect upon IL6 and IL-8 release but inhibited miR-146a expression, whilst blocking p38 MAP kinase inhibited IL-8 but not IL-6 or miR-146a production. In order to confirm these pharmacological studies, we also attempted to use siRNA-mediated knockdown to examine the role of IKK2 and the MAP kinases. Unfortunately, this was not possible since transfection with control siRNA blocked IL-1 $\beta$ induced miR-146a expression (data not shown), possibly through competition between siRNA and primary/precursor miR-146a in the miRNA processing pathway.

Overall, pharmacological studies indicate that IL-1 $\beta$ induced miR-146a expression is regulated via an IKK2-, MEK-1/2- and JNK-1/2-dependent pathway. Significantly, the effect of the JNK inhibitor indicated that IL-

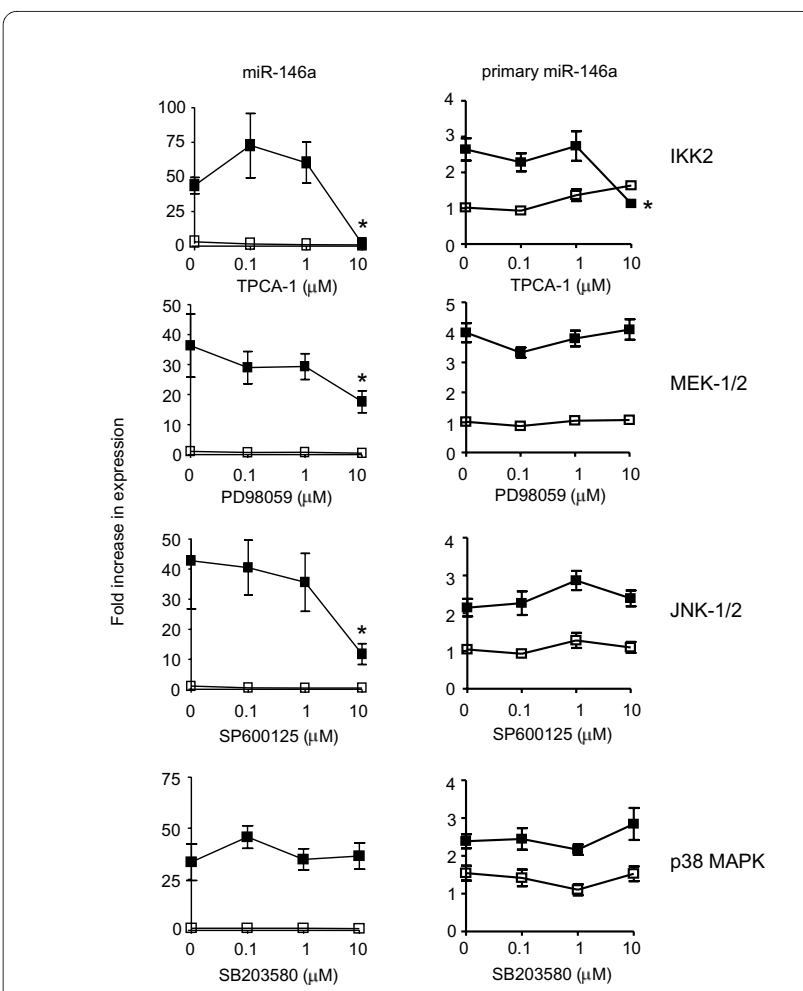

Figure 5 Effect of inhibitors of IKK2 and MAP kinases upon IL-1 $\beta$ induced miR-146a and primary miR-146a expression. HASM cells were pre-treated for $60 \mathrm{~min}$ with the indicated concentrations of the inhibitors of IKK-2 (TPCA-1), MEK-1/2 (PD098059), JNK-1/2 (SP600125) and p38 MAP kinase (SB203580). Following exposure to vehicle control or IL-1 $\beta(1 \mathrm{ng} / \mathrm{ml})$ for $24 \mathrm{~h}$ the expression of miR-146a and primary miR146 a was determined by qRT-PCR. Results are the mean \pm SEM of 3 independent experiments where ${ }^{*} p<0.05$ versus IL-1 $\beta$-stimulated cells.

$1 \beta$-induced miR-146a expression is not central to the regulation of IL- 6 and IL-8 release. Thus, JNK inhibitor concentrations that attenuated mature miR-146a expression had no significant action upon IL- 6 and IL- 8 release.

To ascertain whether the actions of IKK2, MEK-1/2 and JNK-1/2 upon miR-146a expression were mediated at the transcriptional or post-transcriptional level, we also examined the action of these inhibitors upon expression of primary miR-146a (Figure 5). These investigations showed that primary miR-146a levels were attenuated by an inhibitor of IKK2 but not MEK-1/2 or JNK-1/2. Significantly, since these inhibitors were shown to have no effect upon cell viability (Additional File 1), this implied that miR-146a expression was regulated at the transcriptional level through activation of IKK2 (i.e. through NF$\kappa \mathrm{B}$ activity), whilst the post-transcriptional processing of primary miR-146a to produce mature miR-146a is regulated via a MEK-1/2- and JNK-1/2-dependent mechanism. 


\section{IL-1 $\beta$-induced miR-146a expression does not negatively regulate IL- 6 and IL- 8 release}

In contrast to previous studies in alveolar epithelial cells and monocytes/macrophages, the studies using the JNK inhibitor suggested that increased miR-146a expression did not negatively regulate the release of inflammatory mediators. To clarify the role of miR-146a in the inflammatory response of HASM cells, we examined the action of miR-146a inhibitors and mimics on IL- $1 \beta$-induced IL6 and IL-8 release. In support of the observations using the JNK inhibitor, transfection using Amaxa electroporation showed that miR-146a inhibitors, at concentrations up to $100 \mathrm{nM}$, had no significant effect on IL-8 release (Figure 6A). In the case of IL-6, although the miR-146a inhibitor $(100 \mathrm{nM})$ attenuated cytokine release this appeared to be a non-specific effect since this was also seen in the presence of the miRNA control inhibitor (Figure 6A). In contrast, the miR-146a mimic (100 $\mathrm{nM}$ ) produced $23 \%$ and $62 \%$ reduction in IL- $1 \beta$-induced IL- 6 and IL- 8 release, respectively (Figure $6 \mathrm{~B}$ ).
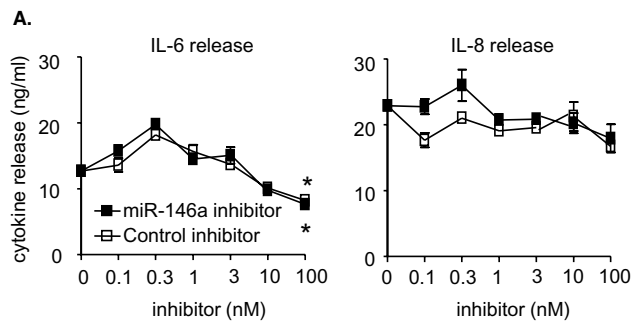

B.
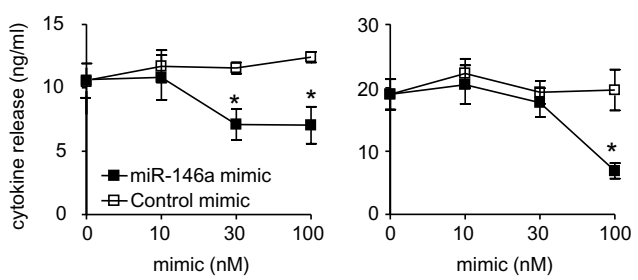

c.
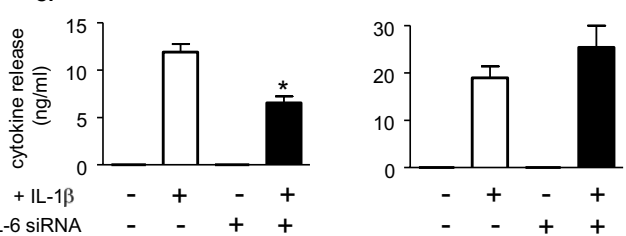

Figure 6 Effect of miR-146a inhibitors and mimics upon IL-1 $\beta$-induced IL-6 and IL-8 release. HASM cells were electroporated in the presence of buffer (A-C), control inhibitor or miR-146a inhibitor (A), control mimic or miR-146a mimic (B) and control siRNA or an siRNA targeted at IL-6 (C). Cells were then exposed to vehicle control or $1 \mathrm{ng} / \mathrm{ml}$ $\mathrm{IL}-1 \beta$ and the release of IL- 6 and IL-8 was measured by ELISA at $24 \mathrm{~h}$. The results are mean \pm SEM of three independent experiments where ${ }^{*} p<0.05$ versus IL-1 $\beta$-stimulated cells.
To confirm efficient transfection, the levels of miR-146a in cells electroporated with miR-146a mimics were measured by TaqMan and showed efficient transfection (Figure 7 - see below). Under the same condition, we have also demonstrated complete abolition of miR-146a expression in the presence of miR-146a inhibitor (data not shown). To provide additional evidence of transfection, we undertook parallel studies that examined the effect of an siRNA (100 nM) targeted to IL-6 and showed a $50 \%$ reduction in IL-6 release but no significant action upon IL-8 generation following IL-1 $\beta$-stimulation (Figure 6C).

To understand the reason that miR-146a mimics reduced IL-1 $\beta$-induced IL- 6 and IL- 8 release (Figure 6B), we measured the levels of miR-146a in HASM cells. These studies were performed following transfection with $100 \mathrm{nM}$ miR-146a mimic since this concentration inhibited IL-1 $\beta$-induced IL- 6 and IL- 8 release (Figure 6B). Significantly, cellular miR-146a levels were increased by 3000-fold following electroporation in the presence of miR-146a mimic, compared with the 20-50-fold increase in response to IL-1 $\beta$ exposure (Figure 7 ). This observation would suggest that although miR-146a mimics can attenuate IL-6 and IL- 8 release, this is a false positive observation that is likely to be due to supra-maximal levels miR-146a levels which cannot be attained following exposure to IL- $1 \beta$. Overall, the studies using JNK- $1 / 2$ and miR-146a inhibitors indicate that IL- $1 \beta$-induced miR146 a expression is not central to the negative feedback regulation of IL- 6 and IL- 8 release.

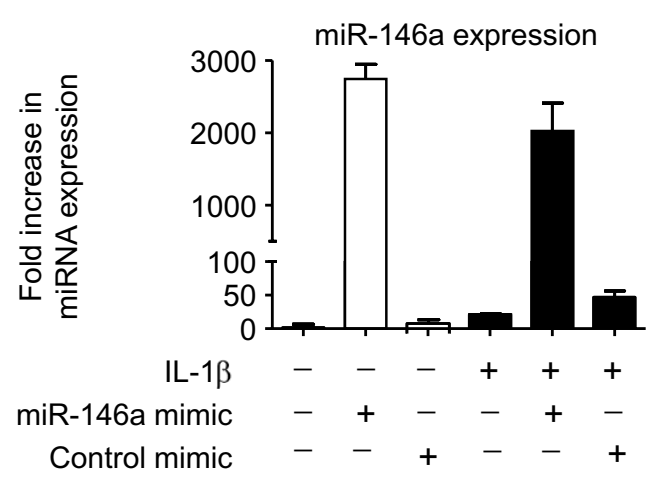

Figure 7 Cellular miR-146a expression levels. HASM cells were electroporated in the presence of buffer, control mimic or miR-146a mimic. Following repeated washes, cells were exposed to vehicle control or $1 \mathrm{ng} / \mathrm{ml} \mathrm{IL-1 \beta}$ and the levels miR-146a were measured by TaqMan RT-PCR at $24 \mathrm{~h}$. The results are mean \pm SEM of three independent experiments. 


\section{IL-1 $\beta$-induced miR-146a expression does not regulate proliferation}

Since previous studies have indicated that changes in miR-146a expression might regulate proliferation in a range of cancer cell lines $[62,63]$ we therefore decided to investigate whether IL-1 $\beta$-induced miR-146a expression might regulate HASM proliferation. Under the fetal calf serum (FCS)-free conditions used in these studies, IL-1 $\beta$ at concentrations up to $10 \mathrm{ng} / \mathrm{ml}$ did not induce a significant increase in HASM proliferation (Figure 8A) or cell number (Figure 8B) at $48 \mathrm{~h}, 72 \mathrm{~h}$ and $96 \mathrm{~h}$. In contrast, FCS induced a concentration-dependent increase in proliferation at $48 \mathrm{~h}$ and $72 \mathrm{~h}$ (Figure $8 \mathrm{~A}$ ) which was reflected in an increase in cell number at $72 \mathrm{~h}$ and $96 \mathrm{~h}$ (Figure 8B). Given that IL-1 $\beta$ failed to impact upon proliferation and cell number, this suggested that miR-146a does not regulate these responses in HASM. To provide additional evidence to support this conclusion, we examined the role of

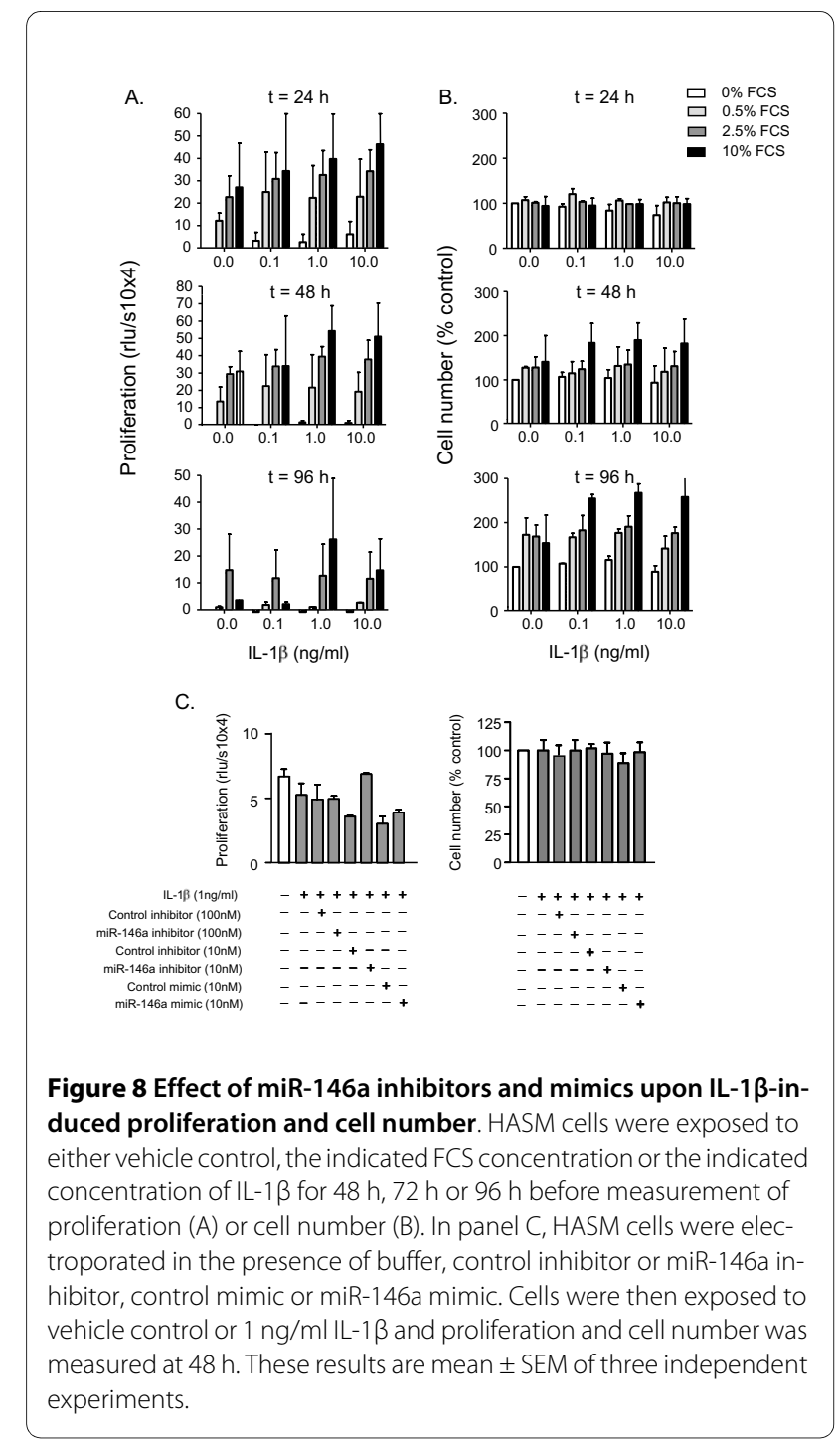

miR-146a inhibitors and mimics at $48 \mathrm{~h}$ upon basal proliferation i.e. in the absence of FCS. From Figure $8 C$, it can be seen that neither miR-146a inhibitors or mimics had an effect upon basal proliferation or cell number in IL-1 $\beta$ stimulated HASM cells.

\section{Mechanism of inhibition of IL- 6 and IL- 8 release by miR- 146a mimics}

Previous studies have indicated that inhibition of inflammatory mediator release by miR-146a is mediated through the down-regulation of IRAK-1 and TRAF6, which have multiple, predicted, miR-146a binding sites and form part of the common intracellular pathway that is activated via TLR/IL-1Rs [32,49]. Therefore, studies were undertaken to determine whether increased miR146a levels following transfection with miR-146a mimics impacted on IRAK-1 and TRAF6 expression. Examination of IRAK-1 and TRAF6 mRNA expression showed a significant reduction of $51 \%$ and $55 \%$ at $24 \mathrm{~h}$ following IL$1 \beta$ stimulation, respectively (Figure 9A). However, this reduction in mRNA expression was not reflected by a concomitant decrease in IRAK-1 and TRAF6 protein expression (Figure 9B). Exposure of non-stimulated cells to the miR-146a mimic resulted in a $84 \%$ and $62 \%$ reduction in the IRAK-1 and TRAF6 mRNA expression and further reductions in IRAK-1 and TRAF6 expression in IL- $1 \beta$-stimulated HASM cells from $51 \%$ to $15 \%$ (IRAK- 1 ) and $55 \%$ to $37 \%$ (TRAF6) (Figure 9A). Significantly, these reductions in IRAK-1 and TRAF6 mRNA levels were also reflected by a decrease in IRAK-1 and TRAF6 protein expression in both control and IL-1 $\beta$-stimulated HASM cells in the presence of miR-146a mimic (Figure 9B). The control mimic had no effect upon IRAK-1 and TRAK6

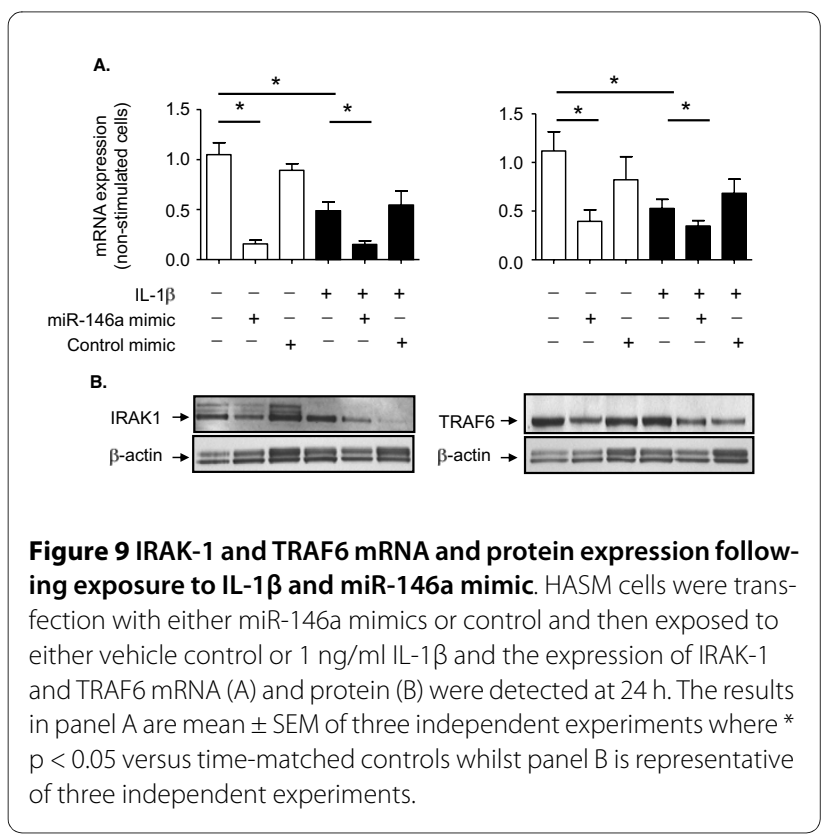


mRNA expression (Figure 9A) but appeared to cause a non-selective reduction in IRAK-1 and TRAF6 protein expression in IL-1 $\beta$ treated but not control cells (Figure $9 \mathrm{~B})$. The reason for this reduction is unknown although we speculate that mimic controls might interact with pathways that regulated IRAK1 and TRAF6 translation but not transcription in activated cells.

Since the miR-146a mimics reduced both IRAK-1 and TRAF6 mRNA and protein expression, we examined whether this could account for the inhibition of IL-6 and IL- 8 release. To this end, we determined the effect of the miR-146a mimics on IL- $1 \beta$ induced IL- 6 and IL- 8 mRNA production. Exposure of HASM cells to IL- $1 \beta$ produced 1100 - and 5700-fold increases in the levels of IL-6 and IL8 mRNA, respectively (Figure 10A). Despite the fact that the miR-146a mimics had been previously shown to attenuate extracellular IL- 6 and IL- 8 release, we observed no significant inhibition of IL- 6 or IL- 8 mRNA expression (Figure 10B). These mechanistic studies indicate that although over-expression of miR-146a following transfection with miRNA mimics can partially down-regulate IRAK-1 and TRAF6 protein expression, this is not responsible for inhibition in IL-6 and IL-8 release from HASM. Instead, the action of the miR-146a mimics is

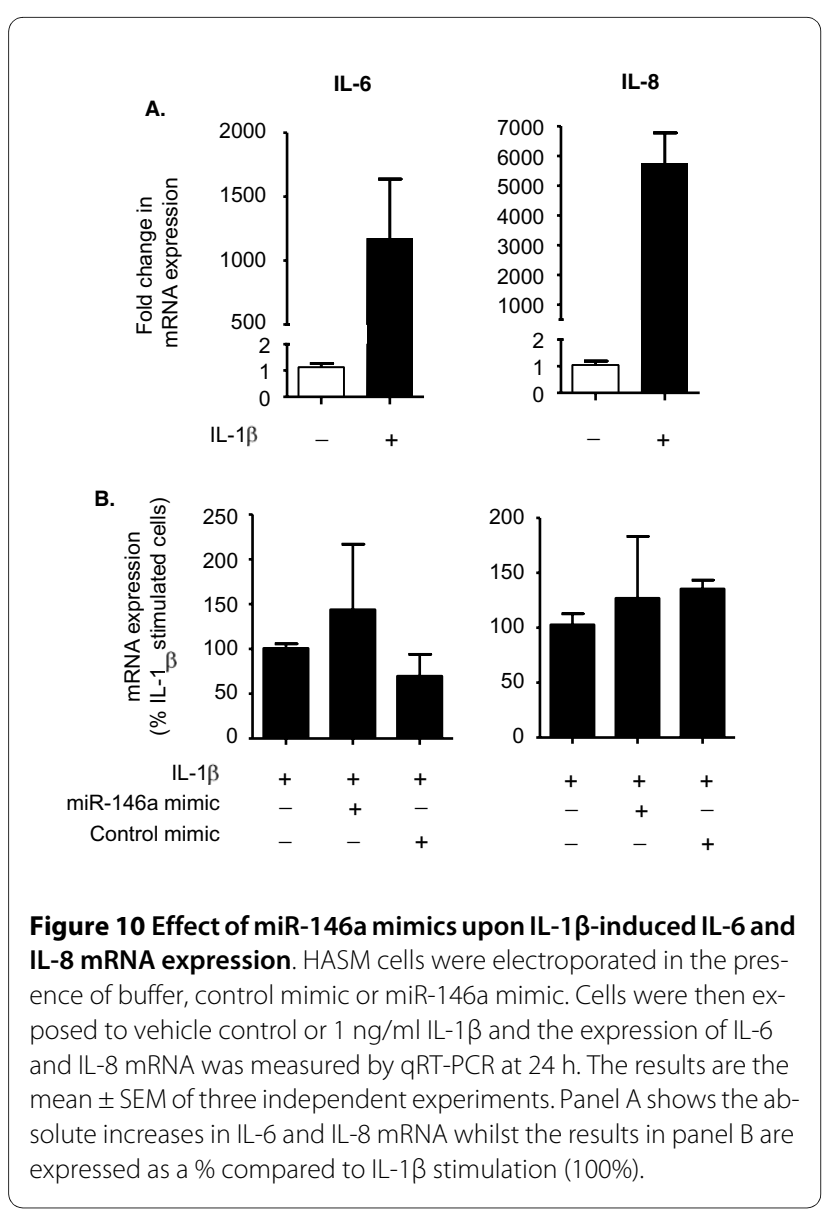

mediated at a post-transcriptional stage following IL-6 and IL- 8 synthesis.

\section{Discussion}

Taganov at al [32] were the first to demonstrate increased miR-146a expression following activation of the TLR/IL$1 \mathrm{R}$ pathway. They also speculated that this might negatively regulate the innate immune response through down-regulation of IRAK-1 and TRAF6, two proteins that are involved in TLR/IL-1R signalling [32]. In the intervening period, the potential role of miR-146a as a negative regulator of the immune response has been highlighted by studies showing TLR/IL-1R-mediated miR-146a expression in multiple cell types and that changes in miR-146a expression is associated with inflammatory diseases including rheumatoid arthritis, osteoarthritis and systemic lupus erythematosus [32,4854]. Surprisingly, only a few of these studies have demonstrated a functional link between miR-146a expression and the release of inflammatory mediators or have attempted to characterise the targets of miR-146a and its mechanism of action. In addition, despite the early demonstration that miR-146a expression is regulated at the transcriptional level through NF- $\mathrm{kB}$ activation, no reports have examined whether miR-146a production is also controlled at the post-transcriptional level $[32,48,49,55,56]$. For this reason, we have characterised the role of miR-146a during IL- $1 \beta$-induced IL- 6 and IL-8 release from primary HASM cells, which are known to contribute towards chronic inflammation associated with the development of asthma.

Initial studies demonstrated IL- $1 \beta$-induced expression of miR-146a but not miR-155, miR-146b or miR-146*. Interestingly, a recent report by Kuhn et al [64] that examined the action of a combination of inflammatory mediators that included IL- $1 \beta$, TNF- $\alpha$ and IFN- $\gamma$ did not observe an increase in miR-146a expression. Instead, this study demonstrated down-regulation of multiple miRNAs and proceeded to show that reduced miR-25 expression increased the release of inflammatory mediators, extracellular matrix turnover and production of contractile proteins through up-regulation of Krüppel-like factor 4 (KLF4), a target of miR-25 [64].

Examination of the kinetics of miR-146a generation showed that this increased throughout the $72 \mathrm{~h}$ period following IL-1 $\beta$ stimulation although there appeared to be differences in the magnitude of the IL- $1 \beta$-induced miR-146a expression, which we believe to be the result of patient-to-patient variation. Interestingly, these observations differed from previous studies in monocytes/macrophages and alveolar epithelial cells, where there was a rapid induction of miR-146a expression that peaked at 6$8 \mathrm{~h}[32,48,49]$. We speculated that this prolonged miR146a expression might impact upon other HASM func- 
tions such as differentiation or contractile potential. Indeed, studies in $\mathrm{C} 2 \mathrm{C} 12$ skeletal muscle cell line have shown cyclic stretch induced miR-146a expression and that this promotes proliferation and inhibits differentiation through down-regulation of Numb, an inhibitor of Notch-induced differentiation [63]. Furthermore, a number of investigators have implicated changes in miR-146a expression in metastasis and proliferation associated with the development of papillary thyroid carcinoma (PTC) [65-67], cervical cancer [68], ovarian cancer [69], breast cancer [69-71], pancreatic cancer [70] and prostate cancer $[70,72]$.

Having demonstrated IL-1 $\beta$-induced miR-146a expression in HASM cells, we next investigated the mechanisms that regulate the transcription of primary miR-146a and its subsequent metabolism to produce the mature miR146a. Previous studies in HASM cells have shown that exposure to IL-1 $\beta$ activates NF-KB (via IKK2) $[6,16,17]$ and the MAP kinase pathways terminating at ERK-1/2, JNK-1/2 and p38 MAP kinase [6,10,17-21]. Therefore, established pharmacological inhibitors that had previously been shown to attenuate IKK2 and MAP kinase activity in HASM [6,10,17-21] were used to examine the role of these intracellular pathways. Significantly, these studies indicated that miR-146a was regulated at both the transcriptional and post-transcriptional level. As previously reported $[32,48,49,55,56]$, we showed that initial transcription of primary miR-146a was mediated through activation of NF- $\mathrm{KB}$. In addition, we have demonstrated that ERK-1/2 and JNK-1/2 but not the p38 MAP kinase pathways regulate the processing of primary miR-146a to produce mature miR-146a. We attempted to confirm these pharmacological observations by using siRNAmediated knockdown of ERK- $1 / 2$ and JNK-1/2 but observed inhibition of IL-1 $\beta$-induced miR-146a production in the presence of control siRNA. Dicer is thought to cleave the precursor miRNA to produce the double stranded miRNA and in combination with TRBP, is required for the loading of both siRNA and miRNAs into the Ago2 containing RISC complex. We therefore speculate that transfected siRNA might compete with precursor miR-146a for Dicer binding and by this route, siRNA could block the production of mature miR-146a. Significantly, competition between siRNA and miRNA has recently been demonstrated by Khan A et al. [73]. Overall, this is the first report demonstrating a role for ERK-1/ 2 and JNK-1/2 pathways in the regulation of miR-146a biogenesis and although the mechanism is presently unknown, we speculate that these MAP kinases might regulate proteins involved in miRNA processing or stability.

Examination of the effect of these MAP kinase inhibitors upon generation of inflammatory mediators showed that IL- 6 release was mediated via NF-KB, ERK-1/2 and p38 MAP kinase whilst IL-8 release was mediated via NFKB and ERK-1/2. Significantly, since neither IL- 6 nor IL-8 release is influenced by the JNK- $1 / 2$ inhibitor, it was possible to use the JNK-1/2 inhibitor to examine the function of miR-146a during IL-1 $\beta$-induced IL- 6 and IL- 8 release.

Previous investigations in alveolar epithelial cells, monocytes and macrophages have shown that increased levels of miR-146a negatively regulate the release of inflammatory mediators $[32,48,49]$. Transfection with miR-146a mimics, which caused a $\sim 3000$-fold increase in cellular miR-146a levels, could also inhibit IL-1 $\beta$-induced IL-6 and IL-8 release in HASM cells. However, we showed that the $\sim 100$-fold increase in miR-146a expression following IL-1 $\beta$ stimulation is insufficient to inhibit IL- 6 and IL-8, since attenuation of miR-146a activity (using a miR-146a inhibitor) or blocking miR-146a expression (using the JNK-1/2 inhibitor) had no significant effect upon cytokine release. It therefore appears that other mechanisms negatively regulate the release of these inflammatory mediators in HASM cells and that the inhibition in the presence of miR-146a mimic is a false positive observation resulting from the high cellular miR-146a levels [74,75].

Since IL-1 $\beta$ has also been shown to induce proliferation in ASM obtained from guinea-pig and rat trachea, we also decided to examine whether changes in miR-146a expression regulated this biological response [11-13]. However, we were unable to show increases in proliferation or cell number in human ASM following IL- $1 \beta$ exposure whilst miR-146a inhibitors and mimics had no effect upon the basal proliferation rate.

We next examined whether increases in miR-146a levels following IL- $1 \beta$ stimulation or transfection with miR146a mimics could target down-regulation of IRAK-1 or TRAF6 protein expression as previously reported in monocytes/macrophages [32,49]. Interestingly, although we observed a reduction in IRAK-1 and TRAF6 mRNA expression following IL-1 $\beta$ exposure, this was not reflected in a reduction in protein levels. In contrast, miR-146a over-expression following transfection with miR-146a mimics caused a partial down-regulation in IRAK-1 and TRAF6 protein expression and a reduction in IL- 6 and IL-8 secretion. However, as with our previous investigations in IL- $1 \beta$-stimulated alveolar epithelial cells [48], the fact that miR-146a mimic failed to inhibit IL-1 $\beta$ induced IL- 6 and IL- 8 mRNA production suggests that its action is mediated at a stage following IL-6 and IL-8 transcription and not through the down-regulation of TRAF6 and IRAK1. Although the mechanism of action is unknown, we speculated that the miR-146a mimic might down-regulate protein(s) involved in one or more steps including IL-6 and IL-8 translation and/or secretion. 


\section{Conclusion}

We have shown that IL-1 $\beta$-induced a time- and concentration-dependent increase in miR-146a expression. As with miR-155 and the regulation of the immune response [30], we demonstrate that the function of miR-146a expression is cell-type specific. Thus, unlike alveolar epithelial cells and monocytes/macrophages, increased miR146a expression following activation of the innate immune response does not appear to negatively regulate the release of inflammatory mediators in HASM cells. This may reflect the fact that the increases in miR-146a expression were insufficient to down-regulate the expression of IRAK-1, TRAF6 or other proteins that are involved in regulating the release of inflammatory mediators $[32,48,49]$. We have also shown that unlike ASM derived from guinea-pigs and rats, IL-1 $\beta$ does not induce proliferation in HASM and that IL-1 $\beta$-induced miR-146a expression does not regulate basal proliferation in HASM. Interestingly, this study also demonstrates that the processing of primary miR-146a is regulated by the MAP kinases, ERK-1/2 and JNK-1/2. Given that activation of these MAP kinases has been demonstrated in a host of biological responses, it will be interesting to determine the mechanism by which MAP kinases regulate the biogenesis of miR-146a and other miRNAs.

\section{Additional material}

\section{Additional file 1 Effect of inhibitors of IKK2 and MAP kinases upon}

HASM cell viability. HASM cells were pre-treated for $60 \mathrm{~min}$ with the indicated concentrations of the inhibitors of IKK-2 (TPCA-1), MEK-1/2 (PD098059), JNK-1/2 (SP600125) and p38 MAP kinase (SB203580). Following exposure to IL-1 $\beta(1 \mathrm{ng} / \mathrm{ml})$ for $24 \mathrm{~h}$, cell viability was measured using an MTT assay. Results are expressed as the \% of non-treated cells and are the mean \pm SEM of 3 independent experiments.

\section{Competing interests}

The authors declare that they have no competing interests.

\section{Authors' contributions}

HML performed all the cell based studies and drafted the manuscript; ET and XJ measured the levels of primary miR-146a, AEW and MMP participated in the conception and design of the study: KFC and MAL participated in the conception and design of the study and were involved in drafting the manuscript. All authors have read and approved the final manuscript.

\section{Acknowledgements}

We would like to thanks Prof. David Baltimore and Dr Mark Boldin of the California Institute of Technology, San Diego USA for providing RT-PCR primers for measurement of primary miR-146a. This work was supported by the National Heart and Lung Institute PhD Studentship (HML), Wellcome Trust (076111 to MAL and AEW; 085935 to KFC), Asthma UK (07/015 to MMP), NIHR Translational Research Facility Grant (ET), NIHR Royal Brompton Respiratory Biomedical Research Unit (KFC) and Chinese Overseas Study Scholarship (XJ).

\section{Author Details}

${ }^{1}$ Airway Disease, National Heart and Lung Institute, Imperial College London SW3 6LY, UK and 2NIHR Translational Research Facility in Respiratory Medicine, University of Manchester, Education and Research Centre, Wythenshawe Hospital, Southmoor Road, Manchester M23 9LY, UK

Received: 14 January 2010 Accepted: 2 June 2010

Published: 2 June 2010
References

1. Holgate ST, Price D, Valovirta E: Asthma out of control? A structured review of recent patient surveys. BMC Pulm Med 2006, 6(Suppl 1):S2.

2. Holgate ST, Polosa R: The mechanisms, diagnosis, and management of severe asthma in adults. Lancet 2006, 368:780-793.

3. Barnes PJ: Immunology of asthma and chronic obstructive pulmonary disease. Nat Rev Immunol 2008, 8:183-192.

4. Holgate ST: Pathogenesis of asthma. Clin Exp Allergy 2008, 38:872-897.

5. Issa R, Xie S, Lee KY, Stanbridge RD, Bhavsar P, Sukkar MB, Chung KF: GROalpha regulation in airway smooth muscle by IL-1beta and TNF-alpha: role of NF-kappaB and MAP kinases. Am J Physiol Lung Cell Mol Physiol 2006, 291:L66-L74.

6. Wuyts WA, Vanaudenaerde BM, Dupont LJ, Demedts MG, Verleden GM: Involvement of p38 MAPK, JNK, p42/p44 ERK and NF-kappaB in IL1 beta-induced chemokine release in human airway smooth muscle cells. Respir Med 2003, 97:811-817.

7. Issa R, Sorrentino R, Sukkar MB, Sriskandan S, Chung KF, Mitchell JA: Differential regulation of CCL-11/eotaxin- 1 and CXCL-8/IL-8 by grampositive and gram-negative bacteria in human airway smooth muscle cells. Respir Res 2008, 9:30.

8. Xie S, Issa R, Sukkar MB, Oltmanns U, Bhavsar PK, Papi A, Caramori G, Adcock I, Chung KF: Induction and regulation of matrix metalloproteinase-12 in human airway smooth muscle cells. Respir Res 2005, 6:148

9. Pascual RM, Carr EM, Seeds MC, Guo M, Panettieri RA, Peters SP, Penn RB: Regulatory features of interleukin-1beta-mediated prostaglandin E2 synthesis in airway smooth muscle. Am J Physiol Lung Cell Mol Physiol 2006, 290:L501-L508.

10. Oltmanns U, Issa R, Sukkar MB, John M, Chung KF: Role of c-jun Nterminal kinase in the induced release of GM-CSF, RANTES and IL-8 from human airway smooth muscle cells. Br J Pharmacol 2003, 139:1228-1234

11. De S, Zelazny ET, Souhrada JF, Souhrada M: IL-1 beta and IL-6 induce hyperplasia and hypertrophy of cultured guinea pig airway smooth muscle cells. J Appl Physio/ 1995, 78:1555-1563.

12. De S, Zelazny ET, Souhrada JF, Souhrada M: Interleukin-1 beta stimulates the proliferation of cultured airway smooth muscle cells via plateletderived growth factor. Am J Respir Cell Mol Biol 1993, 9:645-651.

13. Zhai W, Eynott PR, Oltmanns U, Leung SY, Chung KF: Mitogen-activated protein kinase signalling pathways in IL-1 beta-dependent rat airway smooth muscle proliferation. Br J Pharmacol 2004, 143:1042-1049.

14. O'Neill LA: When signaling pathways collide: positive and negative regulation of toll-like receptor signal transduction. Immunity 2008, 29:12-20.

15. Dinarello CA: Immunological and inflammatory functions of the interleukin-1 family. Annu Rev Immunol 2009, 27:519-550.

16. Birrell MA, Hardaker E, Wong S, McCluskie K, Catley M, De Alba J, Newton R, Haj-Yahia S, Pun KT, Watts CJ, et al:: Ikappa-B kinase-2 inhibitor blocks inflammation in human airway smooth muscle and a rat model of asthma. Am J Respir Crit Care Med 2005, 172:962-971.

17. Wang CC, Lin WN, Lee CW, Lin CC, Luo SF, Wang JS, Yang CM: Involvement of p42/p44 MAPK, p38 MAPK, JNK, and NF-kappaB in IL1 beta-induced VCAM-1 expression in human tracheal smooth muscle cells. Am J Physiol Lung Cell Mol Physiol 2005, 288:L227-L237.

18. Laporte JD, Moore PE, Lahiri T, Schwartzman IN, Panettieri RA, Shore SA: p38 MAP kinase regulates IL-1 beta responses in cultured airway smooth muscle cells. Am J Physiol Lung Cell Mol Physiol 2000, 279:L932-L941.

19. Laporte JD, Moore PE, Abraham JH, Maksym GN, Fabry B, Panettieri RA Shore SA: Role of ERK MAP kinases in responses of cultured human airway smooth muscle cells to IL-1beta. Am J Physiol 1999, 277:L943-L951.

20. Hedges JC, Singer CA, Gerthoffer WT: Mitogen-activated protein kinases regulate cytokine gene expression in human airway myocytes. Am J Respir Cell Mol Biol 2000, 23:86-94.

21. Hallsworth MP, Moir LM, Lai D, Hirst SJ: Inhibitors of mitogen-activated protein kinases differentially regulate eosinophil-activating cytokine release from human airway smooth muscle. Am J Respir Crit Care Med 2001, 164:688-697.

22. Bartel DP: MicroRNAs: target recognition and regulatory functions. Cell 2009, 136:215-233.

23. Filipowicz W, Jaskiewicz L, Kolb FA, Pillai RS: Post-transcriptional gene silencing by siRNAs and miRNAs. Curr Opin Struct Biol 2005, 15:331-341. 
24. Winter J, Jung S, Keller S, Gregory RI, Diederichs S: Many roads to maturity: microRNA biogenesis pathways and their regulation. Nat Cell Biol 2009, 11:228-234

25. Kim VN, Han J, Siomi MC: Biogenesis of small RNAs in animals. Nat Rev Mol Cell Biol 2009, 10:126-139.

26. Lewis BP, Shih IH, Jones-Rhoades MW, Bartel DP, Burge CB: Prediction of mammalian microRNA targets. Cell 2003, 115:787-798.

27. Doench JG, Sharp PA: Specificity of microRNA target selection in translational repression. Genes Dev 2004, 18:504-511.

28. Didiano D, Hobert O: Perfect seed pairing is not a generally reliable predictor for miRNA-target interactions. Nat Struct Mol Biol 2006 13:849-851

29. Lindsay MA: microRNAs and the immune response. Trends Immunol 2008, 29:343-351.

30. Tsitsiou E, Lindsay MA: microRNAs and the immune response. Curr Opin Pharmacol 2009, 9:514-520.

31. Taganov KD, Boldin MP, Baltimore D: MicroRNAs and immunity: tiny players in a big field. Immunity 2007, 26:133-137.

32. Taganov KD, Boldin MP, Chang KJ, Baltimore D: NF-kappaB-dependent induction of microRNA miR-146, an inhibitor targeted to signaling proteins of innate immune responses. Proc Natl Acad Sci USA 2006, 103:12481-12486.

33. O'connell RM, Taganov KD, Boldin MP, Cheng G, Baltimore D: MicroRNA155 is induced during the macrophage inflammatory response. Proc Natl Acad Sci USA 2007, 104:1604-1609.

34. Tili E, Michaille JJ, Cimino A, Costinean S, Dumitru CD, Adair B, Fabbri M, Alder H, Liu CG, Calin GA, et al:: Modulation of miR-155 and miR-125b Levels following Lipopolysaccharide/TNF-\{alpha\} Stimulation and Their Possible Roles in Regulating the Response to Endotoxin Shock. J Immunol 2007, 179:5082-5089.

35. Ceppi M, Pereira PM, Dunand-Sauthier I, Barras E, Reith W, Santos MA, Pierre P: MicroRNA-155 modulates the interleukin-1 signaling pathway in activated human monocyte-derived dendritic cells. Proc Natl Acad SCiUSA 2009, 106:2735-2740

36. Moschos SA, Williams AE, Perry MM, Birrell MA, Belvisi MG, Lindsay MA: Expression profiling in vivo demonstrates rapid changes in lung microRNA levels following lipopolysaccharide-induced inflammation but not in the anti-inflammatory action of glucocorticoids. BMC Genomics 2007, 8:240

37. Bazzoni F, Rossato M, Fabbri M, Gaudiosi D, Mirolo M, Mori L, Tamassia N, Mantovani A, Cassatella MA, Locati M: Induction and regulatory function of miR-9 in human monocytes and neutrophils exposed to proinflammatory signals. Proc Natl Acad Sci USA 2009, 106:5282-5287.

38. Thai TH, Calado DP, Casola S, Ansel KM, Xiao C, Xue Y, Murphy A, Frendewey $D$, Valenzuela D, Kutok JL, et al:: Regulation of the germinal center response by microRNA-155. Science 2007, 316:604-608

39. Ruggiero T, Trabucchi M, De SF, Zupo S, Harfe BD, McManus MT, Rosenfeld MG, Briata P, Gherzi R: LPS induces KH-type splicing regulatory protein-dependent processing of microRNA-155 precursors in macrophages. FASEB J 2009, 23:2898-2908.

40. O'connell RM, Rao DS, Chaudhuri AA, Boldin MP, Taganov KD, Nicoll J Paquette RL, Baltimore D: Sustained expression of microRNA-155 in hematopoietic stem cells causes a myeloproliferative disorder. J Exp Med 2008, 205:585-594.

41. O'connell RM, Chaudhuri AA, Rao DS, Baltimore D: Inositol phosphatase SHIP1 is a primary target of miR-155. Proc Natl Acad Sci USA 2009, 106:7113-7118

42. Rodriguez A, Vigorito E, Clare S, Warren MV, Couttet P, Soond DR, van Dongen S, Grocock RJ, Das PP, Miska EA, et al.: Requirement of bic/ microRNA-155 for normal immune function. Science 2007, 316:608-611.

43. Lu LF, Thai TH, Calado DP, Chaudhry A, Kubo M, Tanaka K, Loeb GB, Lee H, Yoshimura A, Rajewsky K, et al:: Foxp3-dependent microRNA155 confers competitive fitness to regulatory T cells by targeting SOCS1 protein. Immunity 2009, 30:80-91.

44. Kohlhaas S, Garden OA, Scudamore C, Turner M, Okkenhaug K, Vigorito E: Cutting Edge: The Foxp3 Target miR-155 Contributes to the Development of Regulatory T Cells. J Immunol 2009, 182:2578-2582.

45. Vigorito E, Perks KL, Abreu-Goodger C, Bunting S, Xiang Z, Kohlhaas S, Das PP, Miska EA, Rodriguez A, Bradley A, et al:: microRNA-155 regulates the generation of immunoglobulin class-switched plasma cells. Immunity 2007, 27:847-859.
46. Dorsett Y, McBride KM, Jankovic M, Gazumyan A, Thai TH, Robbiani DF, Di Virgilio M, San Martin BR, Heidkamp G, Schwickert TA, et al.: MicroRNA155 suppresses activation-induced cytidine deaminase-mediated Myc-lgh translocation. Immunity 2008, 28:630-638.

47. Teng G, Hakimpour P, Landgraf P, Rice A, Tuschl T, Casellas R, Papavasiliou FN: MicroRNA-155 is a negative regulator of activation-induced cytidine deaminase. Immunity 2008, 28:621-629.

48. Perry MM, Moschos SA, Williams AE, Shepherd NJ, Larner-Svensson HM, Lindsay MA: Rapid Changes in MicroRNA-146a Expression Negatively Regulate the IL-1\{beta\}-Induced Inflammatory Response in Human Lung Alveolar Epithelial Cells. J Immuno/ 2008, 180:5689-5698.

49. Hou J, Wang P, Lin L, Liu X, Ma F, An H, Wang Z, Cao X: MicroRNA-146a feedback inhibits RIG-I-dependent Type I IFN production in macrophages by targeting TRAF6, IRAK1, and IRAK2. J Immunol 2009, 183:2150-2158

50. Liu X, Nelson A, Wang X, Kanaji N, Kim M, Sato T, Nakanishi M, Li Y, Sun J, Michalski J, et al:: MicroRNA-146a modulates human bronchial epithelial cell survival in response to the cytokine-induced apoptosis. Biochem Biophys Res Commun 2009, 380:177-182.

51. Yamasaki K, Nakasa T, Miyaki S, Ishikawa M, Deie M, Adachi N, Yasunaga Y, Asahara H, Ochi M: Expression of MicroRNA-146a in osteoarthritis cartilage. Arthritis Rheum 2009, 60:1035-1041.

52. Stanczyk J, Pedrioli DM, Brentano F, Sanchez-Pernaute O, Kolling C, Gay RE, Detmar M, Gay S, Kyburz D: Altered expression of MicroRNA in synovial fibroblasts and synovial tissue in rheumatoid arthritis. Arthritis Rheum 2008, 58:1001-1009.

53. Jones SW, Watkins G, Le GN, Roberts S, Murphy CL, Brockbank SM, Needham MR, Read SJ, Newham P: The identification of differentially expressed microRNA in osteoarthritic tissue that modulate the production of TNF-alpha and MMP13. Osteoarthritis Cartilage 2009, 17:464-472

54. Tang Y, Luo X, Cui H, Ni X, Yuan M, Guo Y, Huang X, Zhou H, de Vries N, Tak PP, et al: MicroRNA-146A contributes to abnormal activation of the type i interferon pathway in human lupus by targeting the key signaling proteins. Arthritis Rheum 2009, 60:1065-1075.

55. Motsch N, Pfuhl T, Mrazek J, Barth S, Grasser FA: Epstein-Barr virusencoded latent membrane protein 1 (LMP1) induces the expression of the cellular microRNA miR-146a. RNA Biol 2007, 4:131-137.

56. Pichler K, Schneider G, Grassmann R: MicroRNA miR-146a and further oncogenesis-related cellular microRNAs are dysregulated in HTLV-1transformed lymphocytes. Retrovirology 2008, 5:100.

57. Davis BN, Hilyard AC, Lagna G, Hata A: SMAD proteins control DROSHAmediated microRNA maturation. Nature 2008, 454:56-61.

58. Trabucchi M, Briata P, Garcia-Mayoral M, Haase AD, Filipowicz W, Ramos A, Gherzi R, Rosenfeld MG: The RNA-binding protein KSRP promotes the biogenesis of a subset of microRNAs. Nature 2009, 459:1010-1014.

59. De Souza PM, Kankaanranta H, Michael A, Barnes PJ, Giembycz MA, Lindsay MA: Caspase-catalyzed cleavage and activation of Mst1 correlates with eosinophil but not neutrophil apoptosis. Blood 2002, 99:3432-3438

60. Hacker H, Redecke V, Blagoev B, Kratchmarova I, Hsu LC, Wang GG, Kamps MP, Raz E, Wagner H, Hacker G, et al:: Specificity in Toll-like receptor signalling through distinct effector functions of TRAF3 and TRAF6. Nature 2006, 439:204-207.

61. Takaesu G, Ninomiya-Tsuji J, Kishida S, Li X, Stark GR, Matsumoto K: Interleukin-1 (IL-1) receptor-associated kinase leads to activation of TAK1 by inducing TAB2 translocation in the IL-1 signaling pathway. Mol Cell Biol 2001, 21:2475-2484.

62. Williams AE, Perry MM, Moschos SA, Larner-Svensson HM, Lindsay MA: Role of miRNA-146a in the regulation of the innate immune response and cancer. Biochem Soc Trans 2008, 36:1211-1215.

63. Kuang W, Tan J, Duan Y, Duan J, Wang W, Jin F, Jin Z, Yuan X, Liu Y: Cyclic stretch induced miR-146a upregulation delays $\mathrm{C} 2 \mathrm{C} 12$ myogenic differentiation through inhibition of Numb. Biochem Biophys Res Commun 2009, 378:259-263.

64. Kuhn AR, Schlauch K, Lao R, Halayko AJ, Gerthoffer WT, Singer CA: MicroRNA Expression in Human Airway Smooth Muscle Cells: Role of miR-25 in Regulation of Airway Smooth Muscle Phenotype. Am J Respir Cell Mol Biol 2010, 42:506-513.

65. He H, Jazdzewski K, Li W, Liyanarachchi S, Nagy R, Volinia S, Calin GA, Liu CG, Franssila K, Suster S, et al: The role of microRNA genes in papillary thyroid carcinoma. Proc Natl Acad Sci USA 2005, 102:19075-19080. 
66. Pallante $\mathrm{P}$, Visone R, Ferracin M, Ferraro A, Berlingieri MT, Troncone G, Chiappetta G, Liu CG, Santoro M, Negrini M, et al: MicroRNA deregulation in human thyroid papillary carcinomas. Endocr Relat Cancer 2006, 13:497-508

67. Jazdzewski K, Murray EL, Franssila K, Jarzab B, Schoenberg DR, de la CA: Common SNP in pre-miR-146a decreases mature miR expression and predisposes to papillary thyroid carcinoma. Proc Nat/ Acad Sci USA 2008, 105:7269-7274

68. Wang X, Tang S, Le SY, Lu R, Rader JS, Meyers C, Zheng ZM: Aberrant expression of oncogenic and tumor-suppressive microRNAs in cervical cancer is required for cancer cell growth. PLOS ONE 2008, 3:e2557.

69. Shen J, Ambrosone CB, Dicioccio R, Odunsi K, Lele SB, Zhao H: A Functional Polymorphism in the miR-146a Gene and Age of Familial Breast/Ovarian Cancer Diagnosis. Carcinogenesis 2008, 29:1963-1966.

70. Volinia S, Calin GA, Liu CG, Ambs S, Cimmino A, Petrocca F, Visone R, lorio $M$, Roldo C, Ferracin M, et al:: A microRNA expression signature of human solid tumors defines cancer gene targets. Proc Natl Acad Sci USA 2006, 103:2257-2261

71. Hu Z, Liang J, Wang Z, Tian T, Zhou X, Chen J, Miao R, Wang Y, Wang X, Shen $\mathrm{H}$ : Common genetic variants in pre-microRNAs were associated with increased risk of breast cancer in Chinese women. Hum Mutat 2008, 30:79-84

72. Lin SL, Chiang A, Chang D, Ying SY: Loss of mir-146a function in hormone-refractory prostate cancer. RNA 2008, 14:417-424.

73. Khan AA, Betel D, Miller ML, Sander C, Leslie CS, Marks DS: Transfection of small RNAs globally perturbs gene regulation by endogenous microRNAs. Nat Biotechnol 2009, 27:549-555.

74. Liew FY, Xu D, Brint EK, O'Neill LA: Negative regulation of toll-like receptor-mediated immune responses. Nat Rev Immunol 2005, 5:446-458.

75. O'Neill LA: 'Fine tuning' TLR signaling. Nat Immunol 2008, 9:459-461.

doi: 10.1186/1465-9921-11-68

Cite this article as: Larner-Svensson et al., Pharmacological studies of the mechanism and function of interleukin-1?-induced miRNA-146a expression in primary human airway smooth muscle Respiratory Research 2010, 11:68 